DIW BERLIN

Discussion

Papers
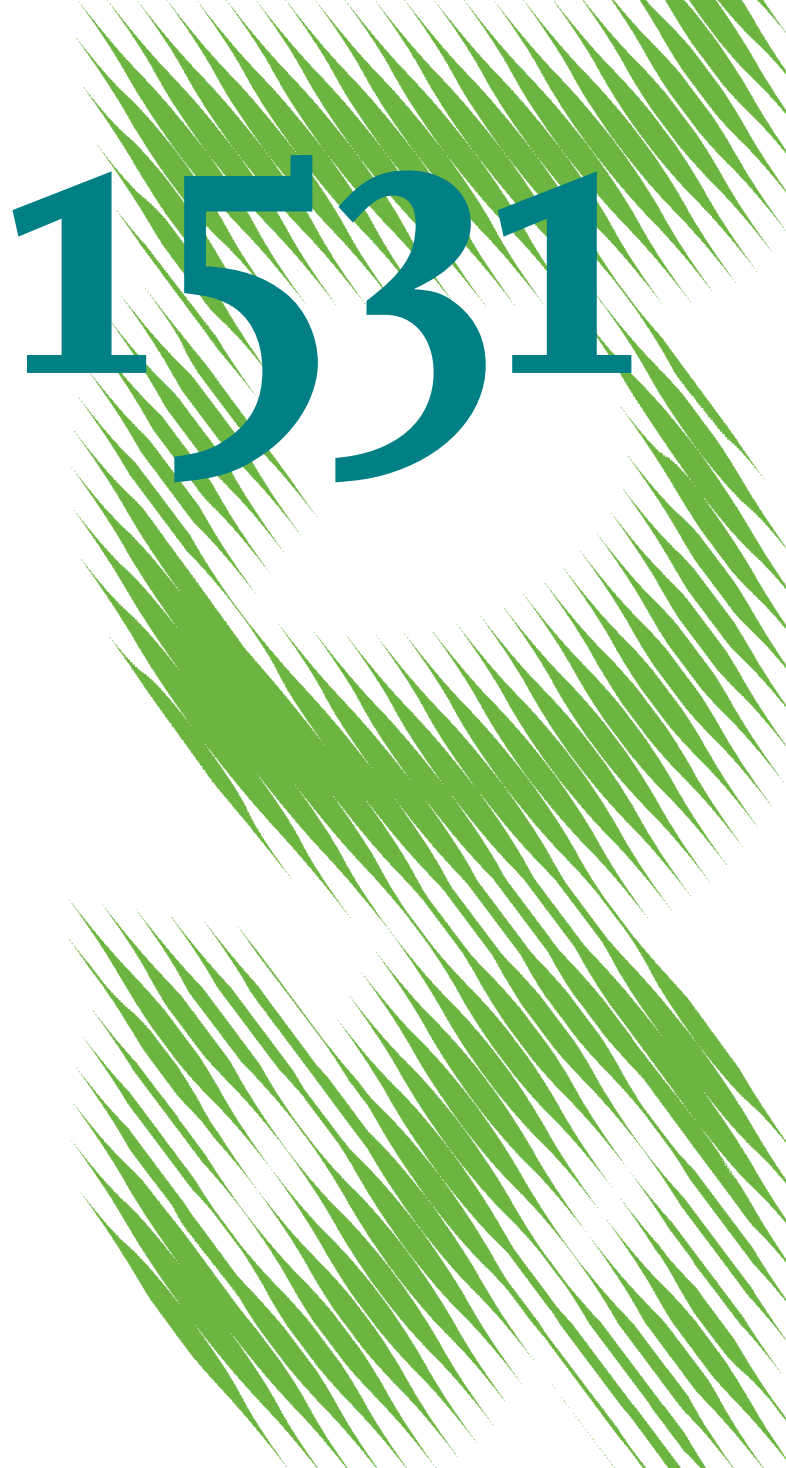

Productivity in Electricity Retail after Market Liberalisation

Analysing the Effects of Ownership and Firm's Governance Structure 
Opinions expressed in this paper are those of the author(s) and do not necessarily reflect views of the institute.

IMPRESSUM

(C) DIW Berlin, 2015

DIW Berlin

German Institute for Economic Research

Mohrenstr. 58

10117 Berlin

Tel. +49 (30) $89789-0$

Fax +49 (30) $89789-200$

http://www.diw.de

ISSN electronic edition 1619-4535

Papers can be downloaded free of charge from the DIW Berlin website:

http://www.diw.de/discussionpapers

Discussion Papers of DIW Berlin are indexed in RePEc and SSRN:

http://ideas.repec.org/s/diw/diwwpp.html

http://www.ssrn.com/link/DIW-Berlin-German-Inst-Econ-Res.html 


\title{
Productivity in Electricity Retail after Market Liberalisation: Analysing the Effects of Ownership and Firm's Governance Structure $^{1}$
}

\author{
Caroline Stiel $^{2,3} \quad$ Astrid Cullmann $^{2} \quad$ Maria Nieswand $^{2}$
}

November 30, 2015

\begin{abstract}
This paper, which is one of the first to estimate productivity in retail electricity for a European country after liberalisation, analyses the effect of ownership and governance structure by using a unique dataset of German electricity retailers from 2003 to 2012. An innovative service production function for the retail sector is derived with labour and external services as the main inputs. A structural model is used with a proxy function for productivity to overcome the endogeneity of input choice. Ownership is controlled for in the law of motion for productivity. The results of the dataset used to validate the model show that firmlevel productivity did not increase after 2008 and that ownership had no effect on productivity. The results provide useful insights into the link between ownership and productivity in modern public enterprises after liberalisation.
\end{abstract}

JEL Classification: D24, L11, C23, L94

Keywords: Productivity, Structural Production Function, Electricity Retail, Ownership, Governance

\footnotetext{
${ }^{1}$ The authors acknowledge financial support from Leibniz Association for the research project KOMIED (Municipal Infrastructure Companies against the Background of Energy Policy and Demographic Change). We thank Ulrich Doraszelski, Tomaso Duso, Pio Baake, Christian von Hirschhausen, Thomas Triebs, Antonio Estache and the participants at NAPW 2014, EARIE 2015 and the conference of the German Economic Association (VfS) 2015 for their comments and suggestions. We thank Ann Stewart for language assistance and proof reading. The usual disclaimer applies. The paper uses restricted data that we analysed at the German Federal Statistical Office Research Data Centre in Berlin. All results have been reviewed to ensure that no confidential information is disclosed.

2 German Institute for Economic Research (DIW Berlin), Department Firms and Markets, Mohrenstrasse 58, D-10117 Berlin, Germany.

${ }^{3}$ Corresponding author: cstiel@diw.de
} 


\section{Introduction}

Starting in 1998, the EU liberalised electricity and natural gas markets in the belief that the introduction of competition would lower retail prices and encourage productivity gains (EC, 2007). However, there is little empirical evidence that productivity has been affected. The reason is that the production processes within the retailing units changed fundamentally after liberalisation. Using Germany as an example, the additional outputs needed to develop marketing and procurement strategies did not increase industry-wide output since coverage is already at $100 \%$. As a consequence, the net effect of liberalisation on productivity ${ }^{4}$ in the retail segment remains ambiguous and largely unstudied. ${ }^{5}$

In many EU countries including Germany, energy policy is influenced by an ongoing political debate which links utility ownership to productivity. Some critics, who claim that public firms are less productive than their private counterparts (see, for instance Germany's Monopolies Commission, 2014), base their arguments on privatisation theories in the tradition of the property rights and principal-agent literature (see, e.g., Laffont and Tirole, 1991; Shleifer and Vishny, 1994; Boycko et al., 1996). The fundamental assumptions are private rent-seeking behaviour among managers and public officials, soft budget constraints, and the absence of transaction costs in regulating private firms. On the other hand, Clò et al. (2014) point to changes in public firm's internal governance structure as well as changes in their operating environments and doubt if the earlier literature on privatization is still relevant with respect to modern public enterprises. In Germany's energy sector, the share of corporated public utilities rose from 38\% in 1990 to 55\% in 2010 (Gottschalk, 2012). The move to abolish local monopolies and promote competition has resulted in more than 1,000 electricity retailers operating in Germany. The average consumer has a choice of more than fifty retailers in a region.

This paper attempts to identify the possible productivity differences between public and private utilities, considering the productivity changes in the retail electricity market for a European country after liberalisation. Our empirical analysis is based on a clearly defined subsample of electricity retailing units derived from a newly available and unique dataset on German utilities operating between 2003 and 2012. Due to Germany's increasingly competitive environment as well as reorganisation within utilities, we hypothesise a minimal impact of ownership on productivity levels. To estimate firm-level productivity, we derive a new Walras-Leontief production function framework for the retail sector, involving a procurement and a marketing decision. We argue that labour and external services are the main inputs for the ser-

\footnotetext{
${ }^{4}$ This paper defines productivity as the amount of inputs a retailer uses to reach a certain number of customers and sell a subsequent level of energy. The paper considers technical productivity without taking into account any allocative inefficiencies.

${ }^{5}$ Only a few studies address production explicitly in the retail segment and those which do cast some doubt on expected productivity gains (e.g., Defeuilley, 2009).
} 
vice production technology of an electricity retailer. We address the endogeneity of input choice using a structural model with the control function approach developed by Olley and Pakes (1996) and extended by Ackerberg et al. (2006). We control for ownership in the law of motion for productivity. This paper differs from Doraszelski and Jaumandreu (2013) in assuming that the ownership status is exogenous to the manager of the retailing company, and from De Loecker and Warzynski (2012) in the sense that private and public firms face the same demand conditions.

This paper is the first empirical study of the performance differences between public and private utilities for Germany and the first estimation of retail productivity after liberalisation altered Europe's traditional energy market structures. The results provide insights into the link between ownership and productivity in modern public enterprises after liberalisation.

The remainder of the paper is organised as follows. Section 2 surveys the published literature on public and private firm ownership and market structures and then focuses on Germany's electricity retail market. Section 3 derives the service production function model and Section 4 presents the empirical strategy. Section 5 describes the dataset and variables. Section 6 discusses the results along with the robustness checks. Section 7 concludes.

\section{Literature survey}

\subsection{Theoretical approaches}

Three distinct streams of thought address the public-private firm comparison: Agency/Property Rights Theory; Public Choice Theory; and Organisation Theory (Villalonga, 2000). These streams postulate two reasons why public firms are less efficient than private firms: managerial discretion and social goals.

Managerial discretion. This hypothesis is based on some moral hazard problem. Managers of public firms are assumed to put less effort into profit-maximisation and instead to maximise a private agenda (e.g., output expansion, leisurely workload) (Williamson, 1963; Alchian, 1965; Migué and Bélanger, 1974; Niskanen, 1968, 1975). Managers are free to do so because of the belief that public firms' disciplining mechanisms or incentive schemes tend to be weak. Reasons involve soft budget constraints (Kornai, 1986), the absence of the market for corporate control (signalling the firm's value and thus the manager's performance, Millward and Parker (1983)), incomplete contracts if the government cannot credibly commit to punish the manager for low effort (Schmidt, 1996) and ex-post expropriation of efficiency gains by the government to serve other (social) goals (Laffont and Tirole, 1991).

Social goals. The pursuit of social goals (e.g., employment) by the owner is central to the second argument. Interest groups are assumed to exert pressure on governments to implement policies through public firms and thus divert a firm's objective away from profit maximisation. While some authors stress that social 
goals may still be ex-post efficient from a welfare point of view (cf. ,common good' hypothesis Wintrobe, 1987; Florio, 2004), more radical contributions assume malevolent governments with private agendas offering few or no social benefit (Shleifer and Vishny, 1994; Boycko et al., 1996). As a consequence, production in public firms would inevitably lead to a deadweight loss in efficiency and welfare.

Other studies emphasise the importance of market structure in determining performance. Studies analysing UK privatisations from 1979 to 1991 (Kay and Thompson, 1986; Yarrow, 1986; Vickers and Yarrow, 1991), find that regulation and market structure are much more relevant for performance than pure transfer of ownership, and that many empirical studies fail to compare ,likes with likes' and to disentangle ownership effects from the influences of regulation and market environment. ${ }^{6}$ While private firms can be more effective at reaching technical efficiency in the absence of market power, allocative efficiency is higher with public firms in the presence of market failure. In other words, government policies should promote competition and effective regulation.

\subsection{Empirical evidence for the electricity sector}

Although traditional economic theory offers manifold suggestions why public firms should perform less efficiently than private companies, empirical evidence is ambiguous and does not easily confirm theory. ${ }^{7}$ The majority of empirical studies on performance differences in the electricity sector examine US utilities in the 1960s to the 1990s. In general, the conclusions drawn about the performance differences between public and private utilities during this period are rather weak. In an overview of the literature, Peters (1993) and Pollitt (1995) point out that many early studies suffer from small sample sizes, overly restrictive assumptions, and failure to account for the impact of market structure, regulation, or vertical integration (see also critique in Atkinson and Halvorsen, 1986). Estimation methods differ and questions addressed range from the study of managers' turnover rates (De Alessi, 1974) to price discrimination (Peltzman, 1971), investment behaviour (Rose and Joskow, 1990), and cost efficiency (Neuberg, 1977). A newer study by Kwoka (2005) using cross-sectional data from 1989 on cost efficiency, finds cost advantages for public firms in electricity distribution, whereas private firms outperform in generation. Moreover, comparisons of performance after partial electricity market restructuring in the US, the development of individual states' renewable portfolio standards, and other changes in federal and state regulatory schemes are scarce.

Studies of the EU's power markets are even scarcer, partly due to the absence of

\footnotetext{
${ }^{6}$ This is particularly true for cross-sector and cross-country studies (see Mühlenkamp, 2013).

7 There exist some general surveys which aim at summarising empirical evidence on performance difference between public and private firms across countries and sectors (see e.g. Megginson and Netter, 2001; Vining and Boardman, 1992). However, these meta surveys neglect any differences in regulation, market structure and firms across industries, countries and time.
} 
relevant datasets. Power markets in Europe tend to be highly concentrated (see, for instance, Enel in Italy and EDF in France) which restricts the available sample sizes. In Sweden, Kumbhakar and Hjalmarsson (1998), who challenge earlier findings by Hjalmarsson and Veiderpass (1992), conclude that private distributors are relatively more cost efficient. Fumagalli et al. (2007) do not find any differences between public and private distributors in Italy when service quality is considered. Arocena and Waddams-Price (2002) investigate the cost efficiency of public and private generators in Spain under different regulatory regimes and show that there is no difference under price-cap regulation, whereas public firms are more cost-efficient under cost-plus regulation. ${ }^{8}$ In summary, despite the attention that economic theory attributes to alleged performance differences between public and private firms, empirical evidence for an important sector of public involvement in Europe, the electricity sector, is rare.

All of the studies above focus on the capital-intense segments, generation and distribution, or analyse vertically integrated utilities. However, production processes fundamentally differ between the capital-intense parts of the value chain and the retailing unit, which is a service business. Furthermore, market structure and regulation are dissimilar, i.e. in the EU, distribution companies are regulated natural monopolies, whereas retail electricity firms must compete in open markets. Our paper contributes to the literature in two ways. It is the first empirical study on performance differences between public and private utilities in Germany. Second, on a global level, it is the first empirical study to explicitly address productivity in energy retail markets, considering the new market structures after European liberalisation.

\subsection{Electricity supply in Germany}

Prior to 1998, electricity in Germany was supplied by more than 800 local monopolists governed by private, public, or mixed ownership. Most were vertically and horizontally integrated and offered other products, such as natural gas and district heating.

EU Directives 96/92/EC and 2003/54/EC, which initiated the reorganisation of the European electricity sector, envisioned a gradual opening of end-consumer markets until 2007. Contrary to other countries, such as France or Italy, the German government decided to liberalise supply to all consumers classes (large industrials, businesses, residential consumers) directly in 1998. Full competition, however, in particular for residential customers, took some time to develop, mainly because third-party access to the distribution networks were negotiated between industry as-

\footnotetext{
${ }^{8}$ Some studies for the UK investigate performance changes after the privatisations (see Florio, 2004, for a summary), but do not allow for a direct comparison of private and public utilities, thus failing to disentangle the effect of ownership from the changes in regulation and market structure.
} 
sociations of retailers and network operators and these contracts lacked transparency (negotiated network access). As a consequence, cumulated consumer switching rates remained around 5\% until 2001 (EC, 2001). Only after the government established a regulatory authority in 2005 to oversee network access and after unbundling reforms in $2007^{9}$ did competition begin to speed up. Still, consumer switching rates in 2008 were significantly lower for residential customers (5\%) than for manufacturing (11\%) and large commercial customers (13\%) (see BNetzA, 2010). Today, depending on the region, residential customers can choose among more than 50 retailers offering a wide range of supply contracts. Most competitors are former local incumbents of other regions along with some new entrants specialising in green energy (Ökostrom) or low-cost tariffs. In 2015, Germany has over 1,000 suppliers, two-thirds of which are majority-owned by public government entities.

\section{Model}

A novel contribution of this paper is the derivation of a service production function for retail electricity, which may include both independent electricity retailers as well as the retailing units within vertically integrated firms. For simplicity, this paper subsumes both under the term ,retailer'. ${ }^{10}$ We exclude horizontally integrated firms in district heat and water supply, for which no separate input data are available, to ensure comparability between firms with respect to homogeneous inputs and outputs.

When specifying the production function in detail, we note that retailers do not produce a physical good but rather provide a service. They are the link between consumers, network operators, and generators. Retailers contract for electricity, in return for which consumers accept a price above the wholesale price, which compensates the retailers. The retailer performs two main activities which determine the success (i.e. profit) of the enterprise: procuring electricity and marketing it. The two activities are explained below.

\subsection{Procurement}

Retailers either purchase electricity from external sources or from generators in their holding company. In the case of external sources, retailers can choose among a variety of contracts, such as long-term contracts, indexed contracts, or procurement in the spot market. The marginal cost of the electricity provided to consumers depends on the portfolio of contracts chosen. For example, in Germany, retail prices

${ }^{9}$ These reforms imposed the legal separation of the distribution networks with the typical characteristics of a natural monopoly from the generation and retail segments of integrated companies with more than 100,000 customers.

10 The operation of the distribution networks is a distinct step of the value chain and is not considered here. 
for residential customers are adjusted only a few times annually, whereas wholesale electricity prices fluctuate daily. Assuming the risk of price volatility can be interpreted as part of the services provided by a retailer to its customers. Procuring adequate supply by managing price volatility can involve hiring procurement experts or outsourcing. Evidence for Germany shows that in particular small retailers tend to use outsourcing. We model the labour choice related to procurement as a decision between own labour force $L$ and external services $S$.

\subsection{Marketing}

The retailer's objective is to maximise the number of customers and thereby sales. The amount of electricity consumed by a single customer is exogenous to the retailer, i.e. it cannot convince a single consumer to consume more electricity. ${ }^{11}$ To increase sales, a retailer must acquire new customers or at least prevent current customers from switching to its competitors. In Germany, many established electricity retailers develop print advertising and social media campaigns to attract new customers (and remind existing customers about the benefits of staying with the retailer), whereas new entrants will employ a variety of approaches to build a reputation and to overcome the tendency of consumers to stay with their local incumbent. Unlike many consumer products, electricity does not differ in its physical appearance, and thus retailers may engage in ,branding', in order to differentiate their products and services from the competitors. ${ }^{12}$ Retailers may turn to in-house marketing staff or outsourcing to devise campaigns. Again, we translate the labour choice related

11 One might argue that the level of electricity consumption is influenced by electricity prices and thus affected by the retailer's pricing policy, yet the empirical evidence shows that the short-run price elasticity of electricity demand for residential customers is highly inelastic and that even long-run elasticities are rather low. Long-run estimates range from -0.2 to -0.7 and short-run estimates from -0.2 to 0 (Silk and Joutz, 1997; Narayan et al., 2007; Alberini and Filippini, 2011; Blazquez et al., 2013). This is intuitive, since a large percentage of electricity consumption is fixed in the short-run by the types of appliances owned by consumers. Moreover, Nakajima and Hamori (2010) find that the regional deregulation of US electricity retail markets does not seem to increase price responsiveness. A retailer's objective is then to raise market share by maximising the number of customers. Apart from that, there is a strong movement in Germany towards energy efficiency which is accompanied by various government policies that encourage less electricity consumption. Thus, it is infeasible to run marketing campaigns inciting customers to raise their individual consumption.

12 Cf. Florio (2013), p.88: "Competition for water or phone calls cannot be of the same type as for furniture or restaurants. Given the relative homogeneity of the good provided by utilities, one would argue that for the consumer it is mostly a matter of searching for the lowest price. [...] Profit-maximising firms, however, know this and [...] then try to win brand loyalty by obfuscating the essential homogeneity of their supply. This translates into advertising and other marketing expenditure including the offer of multi-product packages. These expenditures are likely increased with the number of entrants, without actually offering the consumer substantial price/quality difference. In a precise sense they are wasteful expenditures, which should be seen as a social cost of market opening, when consumers are not well informed." 
to customer relations as a simple decision between using own labour force $L$ and external services $S$.

\subsection{Capital inputs}

A typical production function contains capital input, so it is useful to think about the relevant capital for service providers. Production functions were originally designed for the manufacturing sector, where machines are considered the capital and the employees operating the machines are the labour. A straightforward extension to the service sector would be to consider computers, office buildings etc. as relevant capital and include them in the production function. The problem is that while a manufacturing firm potentially can increase output by purchasing a new machine, it is not clear why upgrading to faster computers or adding more floorspace should lead to more customers. Unlike brick-and-mortar retail, retail electricity providers mostly rely on an online presence to sell their products and services. They also do not need to build and operate distribution centres to stock commodities. Concluding that physical capital does not appear to be a major driver behind productivity, we abstract from capital in our service production function. ${ }^{13}$

\subsection{The service production process as applied to retail electricity}

We begin by following the Walras-Leontief production function,

$$
Q=\min \left(Q_{1}, Q_{2}\right)
$$

where $Q_{1}$ is the amount of the retail product in stock (in our case, procured electricity) and $Q_{2}$ is the potential output created by the combination of marketing and a competitive procurement strategy. $Q_{2}$ is a function of labour and external services $F(L, S)$ and is measured as the number of customers multiplied by their consumption. Output $Q$ is the actual output, i.e. the potential amount of electricity supplied adjusted for the physical limitations in procurement. A retailer can substitute within $F_{2}$, but not between $Q_{1}$ and $Q_{2}$. The Leontief condition expresses the fact that the retailer is not trained in producing the commodity, i.e. it cannot tell labour to produce electricity to meet a spike in consumer demand. The assumption is intuitive in the case of independent electricity retailers that do not own generation. In a vertically integrated firm, managers are responsible for different units. The retailing unit cannot produce more electricity, because the retail staff are white-collar workers and do not have access to the power plant. The production decision of the generation unit is exogenous to the manager of the retail department

13 We could argue that intangible capital matters in this context. It is the motivation and the abilities of the labour force (creativity, innovation, identifying customer needs), which are often subsumed under the term of human capital. Accounting for human capital in general is very difficult due to data availability and is beyond the scope of this paper. 
whose decision is the focus of our model. ${ }^{14}$ The final output is determined by the limiting factor of $Q_{1}$ and $Q_{2}$. In practice, however, $Q_{1}$ is not the limiting factor, because electricity demand is always met by production and the retailer is forced to continually adjust its procurement via the spot market. ${ }^{15}$ In this situation, total output $Q$ is then given by the outcome of $F_{2}$ and the Leontief function reduces to

$$
Q=Q_{2}=F_{2}(L, S)
$$

\section{Empirical strategy and identification}

We approximate the service production function in (2) by a second order Taylor series with the median as the focal point. This translates to a translog production function with median-corrected inputs and outputs (Boisvert, 1982). The translog function provides more flexibility regarding the elasticities of substitution between input factors. It is standard in the utility sector (Kumbhakar, 1996; Saal et al., 2007; Farsi and Filippini, 2009) and is also applied to productivity estimation (e.g., De Loecker and Warzynski, 2012). We additionally control for level effects in the production function which resulting from different customer structures. A retailer with a high share of residential customers in end-consumers will sell less electricity than retailers specialising in manufacturing customers. Likewise, firms that sell to other retailers will have a higher per-customer output of electricity delivered. The estimation equation of the service production function is then given by

$$
\begin{aligned}
q_{i t}= & \beta_{0}+\beta_{l} l_{i t}+\beta_{s} s_{i t}+0.5 \beta_{l l} l_{i t}^{2}+0.5 \beta_{s s} s_{i t}^{2}+\beta_{l s} l_{i t} s_{i t} \\
& +\beta_{\tau} \tau_{i t}+\beta_{\pi} \pi_{i t}+\omega_{i t}+u_{i t},
\end{aligned}
$$

where $i$ is the firm in the year $t, q_{i t}$ is total supply $(\operatorname{logs}), \beta_{0}$ is a constant, $l_{i t}$ is the number of employees (in logs), $s_{i t}$ is deflated expenditure for external services (in $\operatorname{logs}), \tau_{i t}$ controls for the share of electricity delivered to residential customers, $\pi_{i t}$ is the share of electricity supplied to other retailers, $\omega_{i t}$ denotes unobserved technical productivity, and $u_{i t}$ captures iid errors.

We note that when estimating a production function with unobserved productivity $\omega_{i t}$, productivity is likely to affect input choice, which leads to an endogeneity

\footnotetext{
${ }^{14}$ Exogeneity holds at least from a short-term perspective. The retailer could influence generation decisions in the long-run, i.e. by procuring more electricity from renewable energy sources, but doing so would not affect the substitutability of inputs expressed in the Leontief condition.

15 Imagine, by contrast, a retail market for notebook computers, where a customer walks into the retailer's brick-and-mortar store and wants to purchase ten notebooks. Unfortunately, the retailer has only three in stock. When the retailer explains that it will take three months to procure the remaining seven, the customer is unwilling to wait. The retailer's marketing campaign was successful, i.e. it created a potential output of ten notebooks, but the limiting factor is now physical procurement, i.e. only three notebooks are actually in stock.
} 
problem, the so-called simultaneity bias. Olley and Pakes (1996), who were the first to introduce a control function approach meant to overcome the simultaneity bias, divide the estimation process into two stages. In the first stage, productivity is expressed in terms of observables with the help of the input demand function of a static, flexible input. The service production function is estimated by OLS. In a second stage, unbiased coefficients are estimated using moment conditions on the innovation in productivity and past input choice. ${ }^{16}$ Our estimation strategy builds on the extension of Ackerberg et al. (2006) (ACF). The ACF approach explicitly allows for modelling labour as a dynamic, non-flexible input, which reflects the legal situation in the German utility sector and it does not rely on investment as a proxy function for productivity. We do not model capital in the service production process and therefore we do not use capital investment as a proxy. ${ }^{17}$

\section{First stage estimation}

Assume external services $s_{i t}$ to be a static, flexible input without any dynamic implications and with no adjustment costs. Assume that most contracts for external services are adjusted at least once annually and that retailers' marketing campaigns are designed for the short term. The input demand function is then determined in a static optimisation problem and given by

$$
s_{i t}=s_{t}\left(l_{i t}, \tau_{i t}, \pi_{i t}, \omega_{i t}, w_{i t}\right),
$$

where $l_{i t}$ is pre-determined, $w_{i t}$ are firm-specific input prices of the substitute (staff wages), and $s_{t}(\cdot)$ is strictly monotone in $\omega_{i t}$. The index $t$ conveys that $s_{t}(\cdot)$ depends on further firm-invariant variables, such as the price-level of external services, which are not explicitly modelled. Except for $\omega_{i t}$, all variables are observed. $s_{t}(\cdot)$ is then inverted for $\omega_{i t}$, giving

$$
\omega_{i t}=h_{t}\left(l_{i t}, \tau_{i t}, \pi_{i t}, w_{i t}, s_{i t}\right),
$$

where $h_{t}(\cdot)$ is modelled as a polynomial series of degree 2 .

The proxy function for productivity (5) is inserted into the service production function (3) to estimate the prediction $\Phi_{i t}(\cdot)$ by OLS. $\Phi_{i t}(\cdot)$ represents the predicted output net of the iid error $u_{i t}$.

\footnotetext{
${ }^{16}$ In the utility sector, performance indicators, such as technical or cost efficiency, are traditionally estimated in the context of frontier models (see Charnes et al., 1978; Aigner et al., 1977, for an introduction). However, these models assume (in-)efficiency to be exogenous, i.e. uncorrelated with input choice.

17 Levinsohn and Petrin (2003), who use material as the proxy for productivity, assume labour to be fully flexible, which gives rise to a collinearity problem between $l_{i t}$ and $s_{i t}$ as pointed out in Ackerberg et al. (2006).
} 


$$
q_{i t}=\underbrace{\beta_{0}+\beta_{l} l_{i t}+\beta_{s} s_{i t}+0.5 \beta_{l l} l_{i t}^{2}+0.5 \beta_{s s} s_{i t}^{2}+\beta_{l s} l_{i t} s_{i t}+\beta_{\tau} \tau_{i t}+\beta_{\pi} \pi_{i t}+h_{t}(\cdot)}_{\Phi_{i t}\left(l_{i t}, s_{i t}, \tau_{i t}, \pi_{i t}, w_{i t}\right)}+u_{i t}
$$

The (unbiased) prediction $\hat{\Phi}_{i t}$ can be used to express productivity as

$$
\omega_{i t}(\boldsymbol{\beta})=\hat{\Phi}_{i t}-\beta_{0}-\beta_{l} l_{i t}-\beta_{s} s_{i t}-0.5 \beta_{l l} l_{i t}^{2}-0.5 \beta_{s s} s_{i t}^{2}-\beta_{l s} s_{i t} l_{i t}-\beta_{\tau} \tau_{i t}-\beta_{\pi} \pi_{i t}
$$

\section{Second stage estimation}

In the second stage, we assume a first-order Markov process for productivity

$$
\omega_{i t}=c+g\left(\omega_{i t-1}\right)+\varphi d_{i t-1}+v_{i t}
$$

and control for public ownership $d_{i t-1}$. We imply that a change in the managerial strategy in response to a new owner takes at least one year to be implemented. Controlling for additional effects in the law of motion for productivity has been studied previously (De Loecker and Warzynski, 2012; Doraszelski and Jaumandreu, 2013; Maican and Orth, 2015). Doraszelski and Jaumandreu, however, estimate endogenous productivity through $\mathrm{R} \& \mathrm{D}$ expenditure, whereas we assume that management does not directly control ownership status. By including ownership status in the Markov process for productivity, we test for the pertinence of two theories on public firms (see section 2.1). According to the managerial discretion hypothesis, a change in the ownership structure, e.g., the privatisation of a formerly public firm, should modify managers' incentives for efficient input use and thus affect productivity. Likewise, the pursuit of social goals in a public firm should distract managers from profit maximisation and predict a negative effect on productivity. The Markov process is modelled as a polynomial series of degree 3 .

We then regress $\omega_{i t}$ on $\omega_{i j t-1}$, ownership and a constant term to obtain the residuals $\hat{v}_{i t}$

$$
\hat{v}_{i t}(\boldsymbol{\beta})=\omega_{i t}(\boldsymbol{\beta})-\hat{c}-\hat{\psi}_{1} \omega_{i t-1}(\boldsymbol{\beta})-\hat{\psi}_{2} \omega_{i t-1}^{2}(\boldsymbol{\beta})-\hat{\psi}_{3} \omega_{i t-1}^{3}(\boldsymbol{\beta})-\hat{\varphi} d_{i t-1}
$$

where $\boldsymbol{\beta}$ is the vector of coefficients from the service production function. The parameters $\beta_{0}, \beta_{l}, \beta_{s}, \beta_{l l}, \beta_{s s}, \beta_{l s}, \beta_{\tau}$ and $\beta_{\pi}$ are identified by the respective moment conditions 


$$
E\left[v_{i t}\left(\begin{array}{c}
1 \\
l_{i t} \\
l_{i t}^{2} \\
s_{i t-1} \\
s_{i t-1}^{2} \\
l_{i t} s_{i t-1} \\
\tau_{i t} \\
\pi_{i t}
\end{array}\right)\right]=0
$$

The iterative procedure requires first guesses on the vector $\beta$ which we take from an OLS estimation of the translog service production function without the productivity term.

\section{Variable description and data}

The main limitation for empirical studies of retail electricity in Europe is the lack of firm-level data on input use, customer structure, and ownership status. To overcome these limitations, we use a new panel dataset provided by the German Federal Statistical Office. The rich data include various cost components, output and revenue structures, and other variables related to the production process. The panel dataset comprises all German utilities with more than ten employees which provide electricity, natural gas, district heating, water supply, sewerage, and waste treatment. The utilities have different degrees of vertical and horizontal integration. Depending on the year of observation, the data represent $80-90 \%$ of true electricity consumption in Germany. We use a subsample of independent electricity retailers and the retailing units of legally unbundled firms, which is the only way that allows us to identify input use for retail. ${ }^{18}$ We allow for horizontal integration with gas retail, but compute separate inputs between electricity and gas retail. Our final subsample includes 76 retailers operating up to ten years between 2003 and 2012 $(N=212)$.

\subsection{Inputs and outputs}

The service production function has two inputs, labour $L$, measured in number of workers and expenditure for external services $S$. Expenditure for external services is deflated using the German yearly price index for NACE class M (Professional, scientific and technical activities). ${ }^{19}$ Table 1 lists the summary statistics. We include labour costs in the table to give a better idea of the relative importance of external services in input use. The amounts spent on external services clearly exceed

18 The majority of firms are vertically and horizontally integrated. Unfortunately, input use is only reported at the firm-level, which does not allow for a separate estimation of the retailing unit.

19 The number of workers is reported separately for electricity and gas retail in the data. External services are divided between electricity and gas retail in proportion to the staff ratio. 
those spent on internal staff. Outsourcing is therefore an important factor in retail electricity.

Table 1: Summary statistics

\begin{tabular}{|c|c|c|c|c|c|c|c|c|}
\hline & & $Q 5$ & median & mean & Q95 & $s d$ & sum & $\mathrm{N}$ \\
\hline \multicolumn{9}{|l|}{ employees $L$} \\
\hline public & & 1 & 7 & 47 & 194 & 73 & 3,063 & 65 \\
\hline private & & 2 & 16 & 75 & 437 & 136 & 10,982 & 147 \\
\hline \multicolumn{9}{|l|}{ external services $S$} \\
\hline public & {$[\operatorname{mio} €]$} & 0.02 & 0.66 & 24.5 & 157.4 & 53.3 & 1,595 & 65 \\
\hline private & {$[\operatorname{mio} €]$} & 0.00 & 1.05 & 52.9 & 397.1 & 157.7 & 7,780 & 147 \\
\hline \multicolumn{9}{|l|}{ labour costs } \\
\hline public & {$[\operatorname{mio} €]$} & 0.06 & 0.34 & 3.08 & 16.6 & 5.4 & 200.0 & 65 \\
\hline private & {$[\operatorname{mio} €]$} & 0.04 & 0.51 & 5.58 & 29.3 & 13.7 & 819.7 & 147 \\
\hline \multicolumn{9}{|l|}{ wages $w$} \\
\hline public & {$[€ / \mathrm{h}]$} & 21 & 33 & 34 & 55 & 12 & - & 65 \\
\hline private & {$[€ / h]$} & 16 & 32 & 36 & 73 & 18 & - & 147 \\
\hline
\end{tabular}

Output $Q$, the total amount of electricity supplied by the retailer, is measured in TWh and consists of deliveries to both end-consumers $Q^{e}$ and to other retailers $Q^{o r}$

$$
Q=Q^{e}+Q^{o r} .
$$

We observe that $39 \%$ of the retailers sell to other retailers $\left(Q^{\text {or }}>0\right)$. Table 2 provides summary statistics for $Q$. Note that the distribution is heavily skewed to the right, i.e. few large firms dominate. This is representative of electricity supply in Germany, where many retailers are in fact former municipal incumbents. A few large cities dominate a number of small municipalities. In general, there is much dispersion between very small firms (serving an equivalent of less than 100 inhabitants) and large firms with an output $Q^{e}$ equivalent to the electricity consumption of a large city. Altogether, private firms sell $95 \%$ of the electricity in the sample.

Table 2: Summary statistics for total electricity sold

\begin{tabular}{|c|c|c|c|c|c|c|c|c|}
\hline & & Q5 & median & mean & Q95 & $s d$ & sum & $\mathrm{N}$ \\
\hline \multicolumn{9}{|l|}{ total supply $Q$} \\
\hline public & [TWh] & 0.003 & 0.3 & 1.1 & 5.0 & 1.7 & 69.0 & 65 \\
\hline private & [TWh] & 0.002 & 0.09 & 9.3 & 43.4 & 33.6 & 1,374 & 147 \\
\hline all & [TWh] & 0.002 & 0.1 & 6.8 & 26.1 & 28.2 & 1,443 & 212 \\
\hline
\end{tabular}




\subsection{Control variables and ownership structure}

Retailers produce multiple outputs as they serve different customer groups with distinct consumption patterns. Ideally, this would be modelled through a multioutput production function. ${ }^{20}$ Due to the limited sample size, we refrain from a multi-output approach. However, we control for the importance of each customer group and include the share of residential customer deliveries in supply to endconsumers in the estimation equation

$$
\tau=\frac{\text { supply to residential customers } Q^{r}}{\text { supply to end-consumers } Q^{e}} .
$$

Residential customers (Tarifkunden) are private households and small businesses that are served based on two-part tariffs which are typically adjusted once annually. Large customers (Sondervertragskunden) are manufacturing firms but also government entities, housing associations, and (non-energy) retailers. They are served by variable tariffs which link to the fluctuations in wholesale electricity prices. Since residential customers usually have lower per-capita consumption levels, controlling for their percentage avoids the risk of productivity scores reflecting the customer structure instead of providing an isolated measure of productivity. Likewise, deliveries to other retailers imply higher volumes than those sold to end-consumers. Firms with a large percentage of electricity supplied to other retailers thus would appear to be relatively more productive. We account for it by the share of deliveries to other retailers in total supply

$$
\pi=\frac{\text { supply to other retailers } Q^{\text {or }}}{\text { total supply } Q} .
$$

Table 3 lists the summary statistics for both control variables. While $27 \%$ of private firms do not serve any residential customers, $91 \%$ of public retailers do supply them. The proportion of firms selling to other retailers is balanced and lies around $39 \%$.

\begin{tabular}{|c|c|c|c|c|c|c|}
\hline & Q25 & median & mean & Q75 & $s d$ & $z \operatorname{eros}(\%)$ \\
\hline \multicolumn{7}{|l|}{ share of residential customers $\tau$} \\
\hline public & 0.25 & 0.51 & 0.51 & 0.73 & 0.32 & 9.2 \\
\hline private & 0.57 & 0.77 & 0.71 & 0.94 & 0.27 & 27.2 \\
\hline \multicolumn{7}{|l|}{ share of other retailers $\pi$} \\
\hline public & 0.22 & 0.85 & 0.67 & 0.99 & 0.36 & 61.5 \\
\hline private & 0.17 & 0.42 & 0.44 & 0.56 & 0.29 & 60.5 \\
\hline
\end{tabular}

Table 3: Summary statistics for customer structure

20 Shephard (1971), for instance, introduced the distance function approach for modelling multiple outputs in a production framework, which today is widely used in the frontier literature (see e.g., Saal et al., 2007). 
This paper defines public undertakings as firms where public authorities have a dominant influence by either majority of vote or majority of capital (directive $2000 / 52 / E C)$. Ownership is then measured as a dummy variable $d \in\{0,1\}$ which becomes 1 if public entities own more than $50 \%$ of either shares. Annual ownership data are taken from the survey, Jahresabschlussstatistik öffentlicher Unternehmen und Fonds from the Federal Statistical Office.

$$
d_{i}= \begin{cases}1 & \text { if company has more than } 50 \% \text { public shares } \\ 0 & \text { if company has more than } 50 \% \text { private shares }\end{cases}
$$

In total, we observe 65 public firms and 147 private firms.

\section{Results}

\subsection{Service production function estimates}

Table 4 lists the estimates for the coefficients of the service production function. All coefficients have the expected sign. Moreover, first-order coefficients from the ACF method are lower than in the OLS estimation. This is in line with the earlier literature (Olley and Pakes, 1996; Ackerberg et al., 2006). The intuition is that the OLS estimates will be upward biased if productivity is positively correlated with input choice. The negative coefficient for the interaction term between labour and external services indicates, as expected, that the two inputs behave as substitutes at the median. Furthermore, after correcting for the upward bias we find constant returns to scale at the median level of inputs as the sum of the coefficients of $l_{i t}$ and $s_{i t}$ sum up to one. The first stage confirms that a translog specification seems appropriate despite the small sample size. It also reaffirms the importance of controlling for customer class. A higher share of electricity delivered to residential customers leads to smaller output at the median, whereas a higher share of electricity supplied to other retailers leads to higher output at the median. An obvious drawback of the ACF method is the loss of precision in the second stage of estimation due to numerical optimisation and the block-bootstrap of standard errors.

There is a substantial reduction of observations in the second stage, for which lags are required. However, firms leaving our sample are not necessarily driven out of the market. Most of the observations are lost due to missing values in the input data. Checking the full dataset shows that $95 \%$ of the leaving firms continue to sell electricity. Some offer other lines of products, which is another reason to leave our (narrowly defined) sample. The period (2003-2012) is characterised by massive internal reorganisation as firms respond to regulatory changes and competition, as well as the emergence of new markets, e.g., energy consultancy. 
Table 4: Estimates for the service production function coefficients

\begin{tabular}{|c|c|c|c|}
\hline & \multirow[b]{2}{*}{ variable } & first stage $(O L S)$ & second stage $(A C F)$ \\
\hline & & total supply $q_{i t}$ & total supply $q_{i t}$ \\
\hline \multirow[t]{2}{*}{$\beta_{0}$} & constant & -0.072 & 0.315 \\
\hline & & $(0.173)$ & $(0.260)$ \\
\hline \multirow[t]{2}{*}{$l_{i t}$} & labour & $1.056^{* * *}$ & $0.788^{* * *}$ \\
\hline & & $(0.083)$ & $(0.250)$ \\
\hline \multirow[t]{2}{*}{$l_{i t}^{2}$} & labour ${ }^{2}$ & $0.611^{* * *}$ & 0.188 \\
\hline & & $(0.111)$ & $(0.138)$ \\
\hline \multirow[t]{2}{*}{$s_{i t}$} & external services & $0.445^{* * *}$ & 0.216 \\
\hline & & $(0.056)$ & $(0.192)$ \\
\hline \multirow[t]{2}{*}{$s_{i t}^{2}$} & external services ${ }^{2}$ & $0.130^{* * *}$ & $0.179^{* *}$ \\
\hline & & $(0.031)$ & $(0.082)$ \\
\hline \multirow[t]{2}{*}{$l_{i t} s_{i t}$} & labour $\times$ external services & $-0.348^{* * *}$ & -0.180 \\
\hline & & $(0.054)$ & $(0.136)$ \\
\hline \multirow[t]{2}{*}{$\tau_{i t}$} & share residential customers & $-1.155^{* * *}$ & $-1.256^{* *}$ \\
\hline & & $(0.189)$ & $(0.591)$ \\
\hline \multirow[t]{3}{*}{$\pi_{i t}$} & share other retailers & $1.203^{* * *}$ & $2.058^{* * *}$ \\
\hline & & $(0.218)$ & $(0.676)$ \\
\hline & & $\mathrm{N}=212$ & $\mathrm{~N}=118$ \\
\hline
\end{tabular}

\subsection{Law of motion}

Table 5 lists the results for the estimation of the first-order Markov process for productivity (see equation (8)), controlling for public ownership, $d_{i, t-1}$. Clearly, past productivity affects current productivity. Modelling the Markov process as a nonlinear process of degree 3 instead of a linear $\mathrm{AR}(1)$ provides a good approximation for the true underlying law of motion for productivity. ${ }^{21}$

The private firms do not seem to have a better strategy for dealing with market opening than the public firms. They do not systematically achieve higher productivity gains, or incur fewer losses between 2003 and 2012. Section 6.4 analyses the influence of ownership structure in more detail.

\subsection{Productivity time trend}

Firm-level productivity estimates are computed according to

$$
\hat{\omega}_{i t}=\hat{\Phi}_{i t}-\hat{\beta}_{0}-\hat{\beta}_{l} l_{i t}-\hat{\beta}_{s} s_{i t}-0.5 \hat{\beta}_{l l} l_{i t}^{2}-0.5 \hat{\beta_{s s}} s_{i t}^{2}-\hat{\beta_{l s}} s_{i t} l_{i t}-\hat{\beta}_{\tau} \tau_{i t}-\hat{\beta}_{\pi} \pi_{i t}
$$

${ }^{21}$ Note, however, that the ordinary least-squares estimator produces downwardly biased results in small samples for autoregressive processes (see e.g., Marriot and Pope, 1954). Hence, the true coefficients could be higher. 
Table 5: Estimates for the autoregression

\begin{tabular}{lrr}
\hline & OLS & std.error \\
\cline { 2 - 2 } dependent variable & \multicolumn{2}{c}{ productivity $\omega_{i t}$} \\
constant & 0.057 & $(0.070)$ \\
$\omega_{i t-1}$ & $0.755^{* * *}$ & $(0.075)$ \\
$\omega_{i t-1}^{2}$ & $-0.295^{* * *}$ & $(0.059)$ \\
$\omega_{i t-1}^{3}$ & $-0.074^{* * *}$ & $(0.014)$ \\
$d_{i t-1}$ & 0.061 & $(0.109)$ \\
\hline$N=118$. p-values: $0{ }^{* * *}, 0.01{ }^{* *}$, & $0.05^{* *}$ & 0.1. \\
\hline
\end{tabular}

Figure 1, which illustrates the evolution of productivity over time, shows the mean and median productivity growth based on all firms in the sample $(N=212)$ using 2003 as the reference year. ${ }^{22}$

Figure 1: Productivity growth, 2003-2012

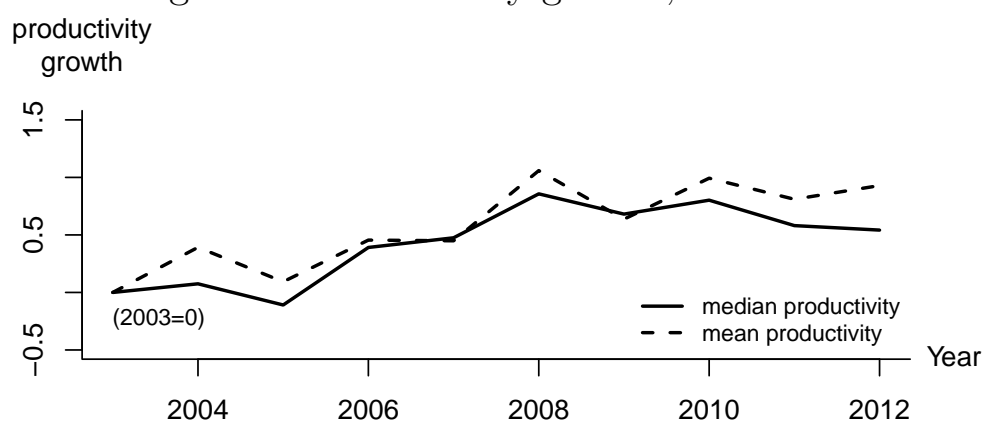

We observe an initial upward trend in mean productivity between 2003 and 2008 . After 2008, both mean and median productivity stabilise. At first glance, the observed evolution in productivity growth is slightly at odds with the developments in the residential customer segment after liberalisation. During the first years, competition among suppliers is mostly limited to large customers, such as commercial clients and the manufacturing sector. Prior to 2007, 97\% change their tariffs, of which $47 \%$ switch from local incumbents (Table 6). ${ }^{23}$ Table 6 also reveals that $93 \%$ of residential households stay with local incumbents, of which $59 \%$ still subscribe to the most expensive baseline tariffs.

22 As the number of firms used in the second stage of estimation is substantially lower, we reproduce the figure based on the reduced sample to verify robustness of our results (see Figure 4 in the appendix). The overall trend is similar.

23 Unfortunately, no figures are available prior to 2007 because the German authorities systematically started to collect data only after 2006 . 
Table 6: Cumulated switching rates (\%)

\begin{tabular}{|c|c|c|c|c|c|c|c|}
\hline & 2007 & 2008 & 2009 & 2010 & 2011 & 2012 & 2013 \\
\hline \multicolumn{8}{|l|}{ households } \\
\hline switch to competitor & 6.4 & 11.2 & 13.9 & 15.5 & 16.8 & 20.1 & 20.9 \\
\hline incumbent low tariff & 35 & 37.8 & 41.2 & 41 & 43.4 & 43.2 & 45 \\
\hline incumbent base tariff & 58.6 & 51 & 44.9 & 43.5 & 39.8 & 36.7 & 34.1 \\
\hline \multicolumn{8}{|c|}{ business and manufacturing } \\
\hline switch to competitor & 46.7 & 47.6 & 48.6 & 51.8 & 54 & 58.6 & 66 \\
\hline incumbent low tariff & 50.2 & 50.3 & 49.3 & 45.8 & 42.8 & 39.3 & 34 \\
\hline incumbent base tariff & 3.1 & 2.1 & 2.1 & 2.4 & 3.1 & 2.1 & $<1$ \\
\hline
\end{tabular}

Figure 2: Consumer switching rates (\%), 2006-2014

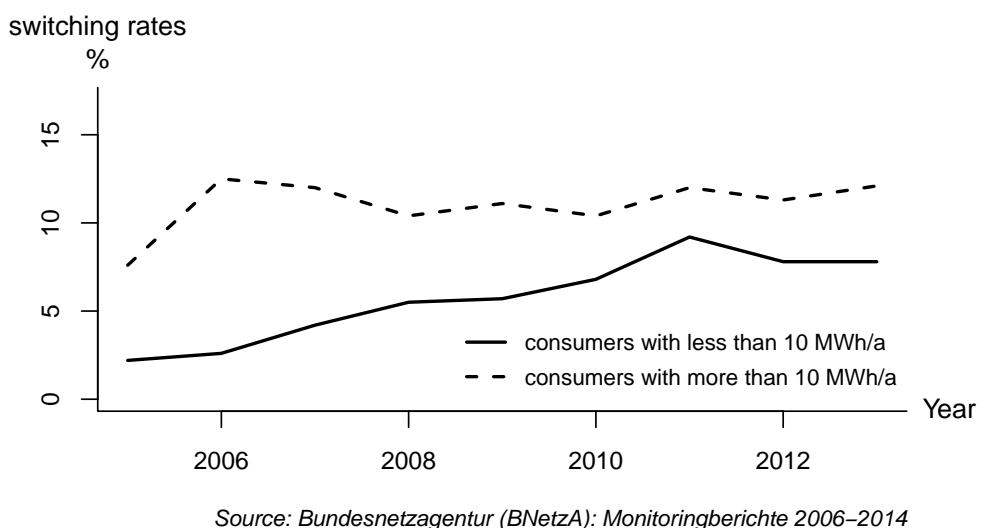

In 2005, Germany's regulatory authority was put in charge of supervising the electricity sector. Centralised regulation significantly reduced discrimination in network access for third parties. As a consequence, switching rates for residential customers slowly increase, more than doubling by 2011 (Figure 2). Switching rates for large customers, on the other hand, remain constant. Likewise, the share of supply areas with more than 50 competitors, which increase from $23 \%$ in 2007 to more than $80 \%$ in 2013, illustrates the intense competition for residential customers after 2007 (Figure 3). 
Figure 3: Competition intensity across supply areas, 2007-2013

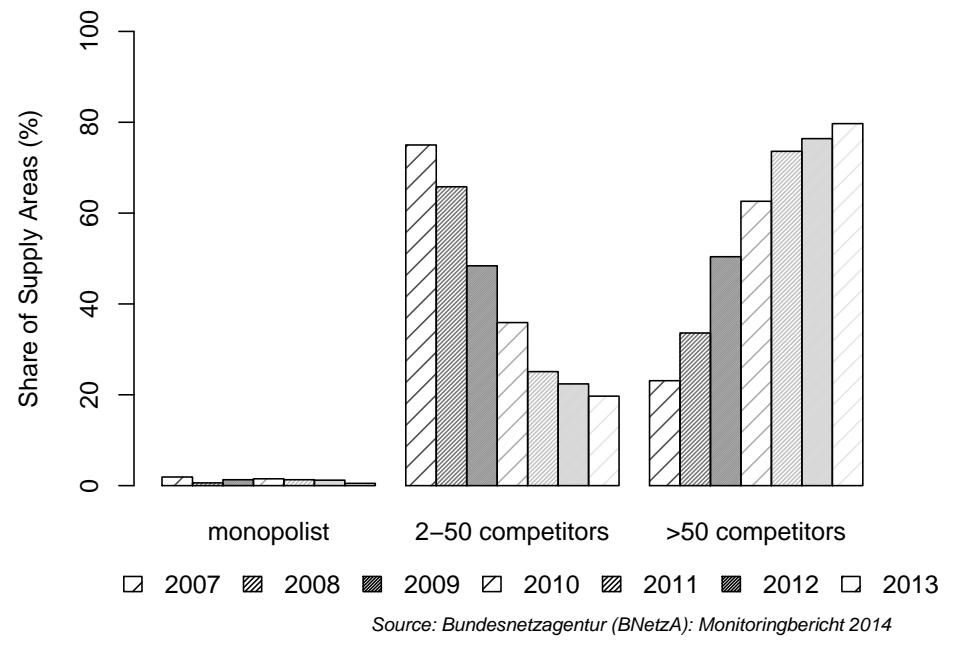

The evolution of productivity growth, however, does not parallel the increased competition for residential customers. Although competition gradually intensifies after 2007, we observe that annual productivity growth is close to zero after 2008 and even becomes negative. The results indicate that reorganisation within firms rather than large-scale competition for consumers drives the productivity gains. During 2003 and 2007, many firms reorganised units, partly in reaction to unbundling requirements, which possibly led to better input use and explains productivity growth. With the start of active competition for residential customers, however, input intensity in the retailing unit of the firms steadily increases without a considerable increase in output, industry-wide. The overall number of residential electricity customers remains constant since coverage is already at 100\%. Also, the amount of electricity consumed remains fairly stable. In contrast, the production process at the retailing stage changes fundamentally (see section 3). Competition, in particular for residential customers, introduces the need for more marketing and enhancing customer relations. At the same time, procurement, which becomes more complex, requires in-house or outsourced expertise. Since all firms have to engage in these additional activities, the higher input requirements likely outweigh the potential productivity gains from competitive pressure.

\subsection{Ownership and productivity}

The first-order Markov process does not control for the base year effect, i.e. the initial productivity level. If public firms start at lower initial productivity levels but the productivity levels evolve at the same rate as private firms, then past productivity captures much of the ownership variation. Therefore, we use an equality of 
means test to check for an overall effect of ownership on productivity. We use a bootstrap algorithm, since our group sample sizes are small and we are unwilling to make any distributional assumptions. The following test is standard and based on Efron and Tibshirani (1993).

We divide the sample into private firms $\left(n_{1}=147\right)$ and public firms $\left(n_{2}=65\right)$. The null hypothesis is

$$
H_{0}: \mathbb{E}\left[\mu_{1}\right]=\mathbb{E}\left[\mu_{2}\right]
$$

against $H_{1}: \mathbb{E}\left[\mu_{1}\right]>\mathbb{E}\left[\mu_{2}\right]$. Productivity values in each group are adjusted according to $\tilde{\omega}_{i j t}=\omega_{i j t}-\bar{\omega}_{n j}+\bar{\omega}_{n}$ with $j=1,2$, such that both groups have equal means under $H_{0}$. We sample from $\left\{\tilde{\boldsymbol{\omega}}_{1}\right\}$ and $\left\{\tilde{\boldsymbol{\omega}}_{2}\right\}$ with replacement. The test statistic is given by

$$
\tau\left(\chi_{b}\right)=\frac{\bar{\omega}_{n 1}^{b}-\bar{\omega}_{n 2}^{b}}{\sqrt{\bar{\sigma}_{n 1}^{2, b} / n_{1}+\bar{\sigma}_{n 2}^{2, b} / n_{2}}},
$$

where $\bar{\sigma}_{n 1}^{2, b}, \bar{\sigma}_{n 2}^{2, b}$ are the respective group variances. The asymptotic sample distribution is computed using the bootstrap algorithm. The p-value is then given by

$$
\hat{p}=\frac{\sum_{b=1}^{B} \mathbb{1}\left(\tau_{b}>\tau_{\text {obs }}\right)}{B},
$$

where $\tau_{b}$ is the test statistic from the bootstrapped sample, $t_{o b s}$ is the observed test statistic for the full sample, and $B=2,000$ is the number of replications. Having estimated a p-value of $\hat{p}=0.663$, we conclude that the null hypothesis cannot be rejected. ${ }^{24}$

\subsection{Governance structure and productivity}

It might not only be the shareholders themselves who matter but also the degree to which they can influence decisions taken within the firm (cf. e.g., (Estrin and Pérotin, 1991)). In Germany, governance differs depending on a firm's legal form. The differences are particularly pronounced for public firms organised under public law and private law. Public law grants less independence to public undertakings. They are subordinate to the local public administration and public officials usually head the firms. Over the last decade, many utilities have changed their legal status by reorganising under private law (e.g., AG, GmbH, GmbH\& Co. KG, and KG). The share of public utilities organised under private law increased from $38 \%$ in 1990 to $55 \%$ in 2010 (Gottschalk, 2012). The governance structure within reorganised public firms is now much closer to that of a private firm and stricter accounting

${ }^{24}$ Calculating the test for the reduced sample $N=118$ from the second stage estimation gives $\hat{p}=0.711$. 
rules apply. Thus, we hypothesise that the difference between public and private firms of the same legal form is small. To verify this, we regress productivity on the legal form interacted with ownership status (see Table 7 ). ${ }^{25}$ We control for time effects.

Table 7: Governance structure and productivity

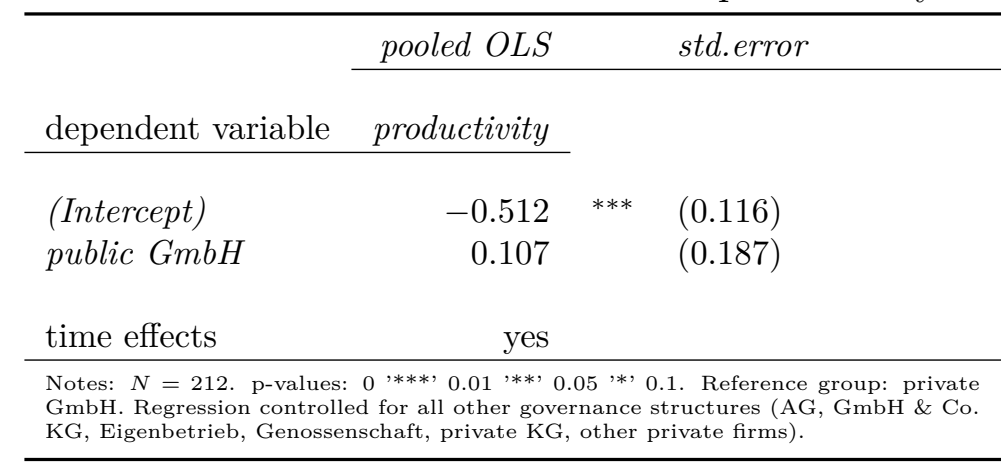

In the sample, $71 \%$ of the public firms and $50 \%$ of the private firms are organised as $G m b H .{ }^{26}$ Since we only observe 65 public firms in total, we focus on public GmbH in relation to our reference group private $G m b H$. We find no difference between public and private firms organised as $G m b H$. GmbH is by far the most common legal form in the retail electricity sector and these firms do not behave differently under competition, whether they are publicly or privately owned. ${ }^{27}$

\subsection{Robustness checks}

We conduct several robustness checks to verify our specification with respect to the influence of demand, the specification of technology, and scale effects. The following sections give the details.

\subsubsection{Demand}

Problems can arise from output being measured as electricity supplied instead of by number of customers. Fluctuations in electricity supply can be caused by demand-side shocks beyond a firm's control. The residual $\omega_{i t}$ would then capture demand shocks rather than productivity (cf. critique in De Loecker, 2011). Therefore, we test for the impact of aggregate demand-side shocks, in particular the 2009

25 Table 8 in the appendix lists the results for the reduced sample from the GMM estimation.

26 Gesellschaft mit beschränkter Haftung is a company with limited liability comparable to Ltd. in the UK or $L L C$ in the US.

27 The interpretation of results for other legal forms deserves caution. Restrained by data, we do not observe enough firms in the remaining subgroups to clearly identify their legal forms as driving the results. Coefficients could be driven by unobserved individual characteristics. 
global economic crisis, by including annual German electricity consumption as a control variable in the service production function. The results for the first stage (OLS) (see column 1, Table 9 in the appendix) suggest that demand-side shocks do not drive the average productivity trend over time. ${ }^{28}$

\subsubsection{Technology}

Public firms can also differ in technology and customer structure. As a consequence, the pooled estimation in section 4 might be too general and the model would be misspecified. We interact the first-order input terms $L_{i t}$, $S_{i t}$ as well as the indicators of the customer structure $\tau_{i t}$ and $\pi_{i t}$ with the ownership dummy to verify this hypothesis. Based on the results listed in column 2 of table 9 , we find no systematic difference in technology and customer structure for both groups.

\subsubsection{Scale}

Output includes supply to other retailers. Perhaps not surprisingly, the estimated impact of serving this particular customer segment on the level of output is strongly positive (cf. table 4). Although the technology coefficients in section 6 suggest constant returns to scale at the median level of inputs, very large firms are not excluded from benefiting from the economies of scale and thus could show higher productivity values. We observe 13 extraordinary large observations in the sample having outputs 200 times that of the median firm. To avoid systematic bias in the productivity values, we ran a sensitivity analysis and excluded all firms with outputs exceeding 20TWh (cf. column 3, 9). We find that the coefficient $\beta_{\pi}$ decreased by one half compared to its original value and was more in line with $\beta_{\tau}$. The group mean tests were unaffected.

\section{Conclusions}

Based on a robust structural model, this paper investigated the evolution of productivity from 2003 to 2012 for electricity retailers in Germany following the imposition of liberalisation. It is the first empirical paper which explicitly addresses productivity in the energy retail markets and which takes account of the new market structure after the start of liberalisation in Europe.

A new service production function for the retail sector was derived, which involved a procurement and a marketing decision. Labour and external services were used as the main inputs. The production function was estimated in a structural model to control for the simultaneity bias, which arises when unobserved productivity is correlated with input choice. A recent and unique dataset of retail electricity providers was used to validate the model.

$\overline{28}$ The limited sample size restricts the study of additional variables to the OLS regression. 
The results found no evidence of ownership having an impact on productivity, possibly due to increasing corporatisation among public utilities and the new competitive environment. The alleged dichotomy between public and private firms therefore, could be exaggerated. The productivity differences between firms could be the result of more complex sources, which suggests that future research should examine precise firm strategies (e.g., green electricity products, branding campaigns, etc.).

Mean productivity increased steadily until 2008 and then levelled off. The finding suggests that productivity gains were driven by firms' reorganisation in response to changing regulation and technology (e.g., procurement) rather than by competitive pressure. When competition intensified after 2008, average productivity remained stable. Demand-side shocks fail to explain the slowdown in productivity growth. Instead, the results emphasise the need for retail firms to engage in marketing activities and complex procurement decisions in the new age of liberalisation. It required additional inputs (e.g., labour force or external services), even as the overall industry output, number of customers, and amount of electricity consumed did not change. Since firms had to engage in these additional activities in order to stay competitive, any productivity gains could have been offset by increasing input requirements. 


\section{References}

Ackerberg, D., Caves, K., Frazer, G., December 28 2006. Structural Identification of Production Functions, Discussion Paper.

Aigner, D., Lovell, K., Schmidt, P., 1977. Formulation and Estimation of Stochastic Frontier Production Function Models. Journal of Econometrics 6 (1), 21-37.

Alberini, A., Filippini, M., 2011. Response of Residential Electricity Demand to Price. The Effect of Measurement Error. Energy Economics 33 (5), 889-895.

Alchian, A., 1965. The Basis of Some Recent Advances in the Theory of Management of the Firm. The Journal of Industrial Economics 14 (1), 30-41.

Arocena, P., Waddams-Price, C., 2002. Generating Efficiency: Economic and Environmental Regulation of Public and Private Electricity Generators in Spain. International Journal of Industrial Organisation 20 (1), 41-69.

Atkinson, S., Halvorsen, R., 1986. The Relative Efficiency of Public and Private Firms in a Regulated Environment: The Case of U.S. Electric Utilities. Journal of Public Economics 29 (3), 281-294.

Blazquez, L., Boogen, N., Filippini, M., 2013. Residential Electricity Demand in Spain: New Empirical Evidence from Aggregate Data. Energy Economics 36 (3), 648-657.

BNetzA, 2006-2014. Monitoringberichte 2006-2014. Tech. rep., Bundesnetzagentur, Bonn.

BNetzA, 2010. Jahresbericht 2009. Tech. rep., Bundesnetzagentur, Bonn.

Boisvert, R., 1982. The Translog Production Function: Its Properties, Its Several Interpretations and Estimation Problems. Tech. rep., Cornell University.

Boycko, M., Shleifer, A., Vishny, R., 1996. A Theory of Privatisation. Economic Journal 106 (435), 309-319.

Charnes, A., Cooper, W., Rhodes, E., 1978. Measuring the Efficiency of Decision Making Units. European Journal of Operational Research 2 (6), 429-444.

Clò, S., Fiorio, C., Florio, M., 2014. Ownership and Performance in the Market for Corporate Control: The Role of State-owned Enterprises. Working Paper No. 2014-17, Università degli Studi di Milano.

De Alessi, L., 1974. Mangerial Tenure under Private and Government Ownership in the Electric Power Industry. Journal of Political Economy 82 (3), 645-653. 
De Loecker, J., 2011. Production Differentiation, Multiproduct Firms, and Estimating the Impact of Trade Liberalization on Productivity. Econometrica 79 (5), $1407-1451$.

De Loecker, J., Warzynski, F., 2012. Markups and Firm-level Export Status. American Economic Review 102 (6), 2437-2471.

Defeuilley, C., 2009. Retail Competition in Electricity Markets. Energy Policy 37 (2), $377-386$.

Doraszelski, U., Jaumandreu, J., 2013. R\&D: Estimating Endogenous Productivity. Review of Economic Studies 80 (4), 1338-1383.

EC, 2001. Communication from the Commission to the Council and the European Parliament. Completing the Internal Energy Market. Tech. Rep. COM(2001) 125 final, European Commission.

EC, 2007. Evaluation of the Performance of Network Industries Providing Services of General Economic Interest. Report 2006 Annexes SEC(2007) 1024, European Commission.

Efron, B., Tibshirani, R., 1993. An Introduction to the Bootstrap. Chapman \& Hall. New York.

Estrin, S., Pérotin, V., 1991. Does Ownership Always Matter? International Journal of Industrial Organization 9 (1), 55-72.

Farsi, M., Filippini, M., 2009. An Analysis of Cost Efficiency in Swiss Multi-utilities. Energy Economics 31 (2), 306-315.

Florio, M., 2004. The Great Divestiture. Evaluating the Welfare Impact of the British Privatizations 1979-1997. MIT Press.

Florio, M., 2013. Network Industries and Social Welfare. The Experiment that Reshuffled European Utilities. Oxford University Press.

Fumagalli, E., Garrone, P., Grilli, L., 2007. Service Quality in the Electricity Industry: The Role of Privatization and Managerial Behavior. Energy Policy 35 (12), $6212-6224$.

Gottschalk, W., 2012. Strukturen und Organisation von Stadtwerken. In: Bräunig, D., Gottschalk, W. (Eds.), Stadtwerke. Grundlagen, Rahmenbedingungen, Führung und Betrieb. Nomos. Baden-Baden.

Hjalmarsson, L., Veiderpass, A., 1992. Efficiency and Ownership in Swedish Retail Distribution. The Journal of Productivity Analysis 3 (1), 7-23. 
Kay, J., Thompson, D., 1986. Privatisation: A Policy in Search of a Rationale. The Economic Journal 96 (381), 18-32.

Kornai, J., 1986. The Soft Budget Constraint. Kyklos 39 (1), 3-30.

Kumbhakar, S., 1996. Estimation of Cost Efficiency with Heteroscedasticity: An Application to Electricity Utilities. Journal of the Royal Statistical Society 45 (3), 319-335.

Kumbhakar, S. C., Hjalmarsson, L., 1998. Relative Performance of Public and Private Ownership under Yardstick Competition: Electricity Retail Distribution. European Economic Review 42 (1), 97-122.

Kwoka, J., 2005. The Comparative Advantage of Public Ownership: Evidence from U.S. Electric Utilities. The Canadian Journal of Economics 38 (2), 622-640.

Laffont, J.-J., Tirole, J., 1991. Privatization and Incentives. Journal of Law, Economics, \& Organization, 84-105.

Levinsohn, J., Petrin, A., 2003. Estimating Production Functions Using Inputs to Control for Unobservables. Review of Economic Studies 70 (2), 317-341.

Maican, F., Orth, M., 2015. A Dynamic Analysis of Entry Regulations and Productivity in Retail Trade. International Journal of Industrial Organization 40 (5), $67-80$.

Marriot, F., Pope, J., 1954. Bias in the Estimation of Autocorrelations. Biometrika 41 (3-4), 390-402.

Megginson, W., Netter, J., 2001. From State to Market: A Survey on Empirical Studies on Privatization. Journal of Economic Literature 39 (2), 321-389.

Mühlenkamp, H., 2013. From State to Market Revisited: More Evidence on the Efficiency of Public (and Privately-owned) Enterprises, MPRA Paper No. 475570.

Migué, J., Bélanger, G., 1974. Toward a General Theory of Managerial Discretion. Public Choice 17 (1), 27-47.

Millward, R., Parker, D., 1983. Public and Private Enterprise: Comparative Behaviour and Relative Efficiency. In: Millward, R., Parker, D., Rosenthal, L., Sumner, M., Topham, N. (Eds.), Public Sector Economics. Longman, London.

Monopolies Commission, 2014. Eine Wettbewerbsordnung für die Finanzmärkte. Zwanzigstes Hauptgutachten der Monopolkommission gemäß § 44 Abs. 1 Satz 1 GWB. Tech. Rep. 2012/2013, Bonn, Monopolies Commission. 
Nakajima, T., Hamori, S., 2010. Change in Consumer Sensitivity to Electricity Prices in Response to Retail Deregulation: A Panel Empirical Analysis of the Residential Demand for Electricity in the United States. Energy Policy 38 (5), 2470-2476.

Narayan, P., Smyth, R., Prasad, A., 2007. Electricity Consumption in G7 Countries: A Panel Cointegration Analysis of Residential Demand Elasticities. Energy Policy 35 (9), 4485-4494.

Neuberg, L., 1977. Two Issues in the Municipal Ownership of Electric Power Distribution Systems. Bell Journal of Economics 8 (1), 303-323.

Niskanen, W., 1968. Nonmarket Decision Making. The Peculiar Economics of Bureaucracy. American Economic Review 58 (2), 293-305.

Niskanen, W., 1975. Bureaucrats and Politicians. The Journal of Law and Economics 18 (3), 617-643.

Olley, G., Pakes, A., 1996. The Dynamics of Productivity in the Telecommunications Equipment Industry. Econometrica 64 (6), 1263-1297.

Peltzman, S., 1971. Pricing in Public and Private Enterprises: Electric Utilities in the United States. Journal of Law and Economics 14 (1), 109-147.

Peters, L., 1993. Non-Profit Electric Utilities in the United States: Pricing and Efficiency. Annals of Public and Cooperative Economics 64 (4), 575-604.

Pollitt, M., 1995. Ownership and Performance in Electric Utilities: The International Evidence on Privatization and Efficiency. Oxford University Press.

Rose, N., Joskow, P., 1990. The Diffusion of New Technologies: Evidence from the Electric Utility Industry. RAND Journal of Economics 21 (3), 354-373.

Saal, D., Parker, D., Weyman-Jones, T., 2007. Determining the Contribution of Technical Change, Efficiency Change and Scale Change to Productivity Growth in the Privatized English and Welsh Water and Sewerage Industry: 1985-2000. Journal of Productivity Analysis 28 (1-2), 127-139.

Schmidt, K., 1996. The Costs and Benefits of Privatization: An Incomplete Contracts Approach. Journal of Law, Economics, and Organization 12 (1), 1-24.

Shephard, R. W., 1971. Theory of Cost and Production Functions. Princeton University Press.

Shleifer, A., Vishny, R. W., 1994. Politicians and Firms. The Quarterly Journal of Economics, 995-1025. 
Silk, J., Joutz, F., 1997. Short and Long-Run Elasticities in US Residential Electricity Demand: A Co-Integration Approach. Energy Economics 19 (5), 493-513.

Vickers, J., Yarrow, G., 1991. Economic Perspectives on Privatization. Journal of Economic Perspectives 5 (2), 111-132.

Villalonga, B., 2000. Privatization and Efficiency: Differentiating Ownership Effects from Political, Organizational, and Dynamic Effects. Journal of Economic Behavior \& Organization 42, 43-47.

Vining, A. R., Boardman, A. E., 1992. Ownership versus Competition: Efficiency in Public Enterprise. Public choice 73 (2), 205-239.

Williamson, O., 1963. Managerial Discretion and Business Behavior. American Economic Review 53 (5), 1032-1057.

Wintrobe, R., 1987. The Market for Corporate Control and the Market for Political Control. Journal of Law, Economics, and Organization 3 (2ol and the Market for Political Control. Journal of Law, Economics, and Organization. 3(2). pp. 435-448.), 435-448.

Yarrow, G., 1986. Privatization in Theory and Practice. Economic Policy 1 (2), $323-364$. 


\section{Appendix}

Figure 4: Productivity growth, 2004-2012: GMM sample

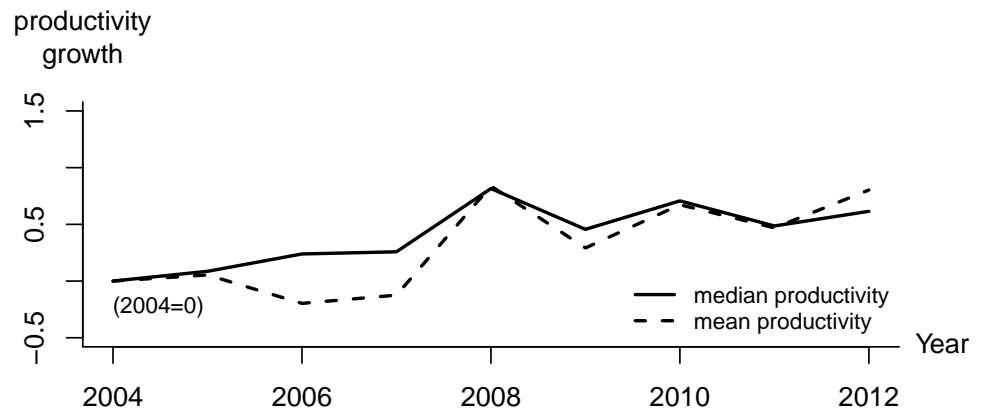

Table 8: Governance structure and productivity: GMM sample

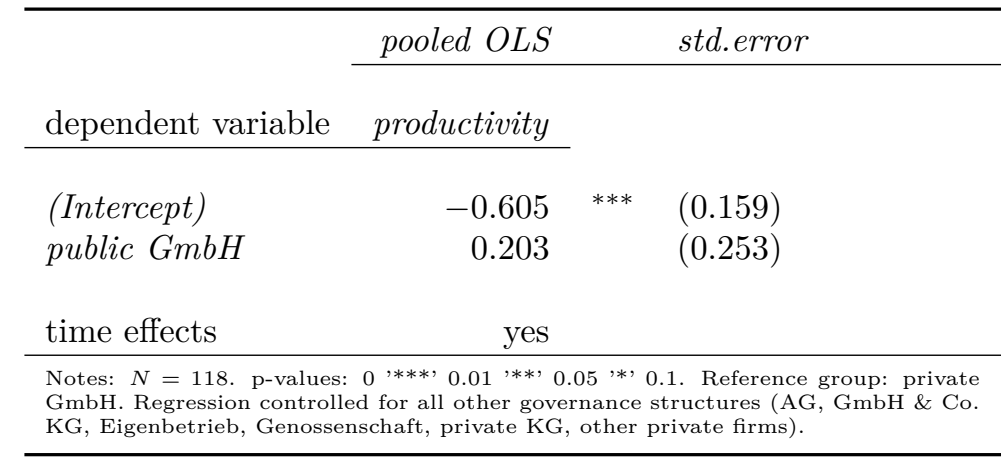


Table 9: Robustness checks

\begin{tabular}{|c|c|c|c|c|}
\hline & & $\frac{I}{O L S}$ & $\begin{array}{l}I I \\
O L S\end{array}$ & $\frac{I I I}{A C F}$ \\
\hline$\beta_{0}$ & constant & $\begin{array}{c}-1.968 \\
(3.539)\end{array}$ & $\begin{array}{c}-0.088 \\
(0.200)\end{array}$ & $\begin{array}{l}0.294 \\
(0.256)\end{array}$ \\
\hline$l_{i t}$ & labour & $\begin{array}{l}1.055^{\text {*** }} \\
(0.083)\end{array}$ & $\begin{array}{l}1.000^{* * *} \\
(0.112)\end{array}$ & $\begin{array}{l}0.427 \\
(0.277)\end{array}$ \\
\hline$l_{i t}^{2}$ & labour ${ }^{2}$ & $\begin{array}{l}0.607^{* * *} \\
(0.111)\end{array}$ & $\begin{array}{l}0.612^{\text {*** }} \\
(0.113)\end{array}$ & $\begin{array}{l}0.187 \\
(0.126)\end{array}$ \\
\hline$s_{i t}$ & external services & $\begin{array}{l}0.443^{* * *} \\
(0.056)\end{array}$ & $\begin{array}{l}0.463^{* * *} \\
(0.060)\end{array}$ & $\begin{array}{l}0.432^{*} \\
(0.229)\end{array}$ \\
\hline$s_{i t}^{2}$ & external services ${ }^{2}$ & $\begin{array}{l}0.129^{* * *} \\
(0.031)\end{array}$ & $\begin{array}{l}0.133^{* * *} \\
(0.031)\end{array}$ & $\begin{array}{l}0.090 \\
(0.076)\end{array}$ \\
\hline$l_{i t} s_{i t}$ & labour $\times$ external services & $\begin{array}{l}-0.345^{* * *} \\
(0.055)\end{array}$ & $\begin{array}{l}-0.338^{* * *} \\
(0.057)\end{array}$ & $\begin{array}{l}-0.126 \\
(0.109)\end{array}$ \\
\hline$\tau_{i t}$ & share residential customers & $\begin{array}{l}-1.164^{* * *} \\
(0.190)\end{array}$ & $\begin{array}{l}-1.327^{\text {*** }} \\
(0.267)\end{array}$ & $\begin{array}{l}-0.949^{* *} \\
(0.439)\end{array}$ \\
\hline$\pi_{i t}$ & share other retailers & $\begin{array}{l}1.217^{* * *} \\
(0.219)\end{array}$ & $\begin{array}{l}1.176^{* * *} \\
(0.329)\end{array}$ & $\begin{array}{l}0.795 \\
(0.594)\end{array}$ \\
\hline & German electricity demand & $\begin{array}{l}0.004 \\
(0.007)\end{array}$ & & \\
\hline$d_{i t}$ & public & & $\begin{array}{l}0.115 \\
(0.276)\end{array}$ & \\
\hline$d_{i t} l_{i t}$ & labour $\times$ public & & $\begin{array}{l}0.124 \\
(0.141)\end{array}$ & \\
\hline$d_{i t} s_{i t}$ & external services $\times$ public & & $\begin{array}{l}-0.027 \\
(0.069)\end{array}$ & \\
\hline$d_{i t} \tau_{i t}$ & share residential customers $\times$ public & & $\begin{array}{l}0.300 \\
(0.419)\end{array}$ & \\
\hline \multirow[t]{4}{*}{$d_{i t} \pi_{i t}$} & share other retailers $\times$ public & & $\begin{array}{l}0.018 \\
(0.422)\end{array}$ & \\
\hline & & $\mathrm{N}=212$ & $\mathrm{~N}=212$ & $\mathrm{~N}=110$ \\
\hline & Group mean test & & & \\
\hline & $\begin{array}{l}\hat{p} \\
\hat{p} \text { GMM sample }\end{array}$ & & & $\begin{array}{l}0.474 \\
0.288\end{array}$ \\
\hline
\end{tabular}

